\title{
Safety and Toxicology of Magnolol and Honokiol
}

\begin{abstract}
Authors
Andrea Sarrica ${ }^{1}$, Natalja Kirika ${ }^{1}$, Margherita Romeo ${ }^{2}$, Mario Salmona², Luisa Diomede ${ }^{2}$

Affiliations

1 Perfetti Van Melle Spa Lainate, Milan, Italy

2 Department of Molecular Biochemistry and Pharmacology, IRCCS - Istituto di Ricerche Farmacologiche "Mario Negri," Milan, Italy

Key words

Magnolia officinalis, Magnoliaceae, toxicity, safety, magnolol, honokiol

received March 23, 2018

revised May 29, 2018

accepted June 6, 2018

Bibliography

DOI https://doi.org/10.1055/a-0642-1966

Published online June 20, 2018 | Planta Med 2018; 84: 1151-

1164 (c) Georg Thieme Verlag KG Stuttgart · New York |

ISSN 0032-0943

Correspondence

Dr. Luisa Diomede

Department of Molecular Biochemistry and Pharmacology,

IRCCS - Istituto di Ricerche Farmacologiche "Mario Negri"

Via G. La Masa 19, 20156 Milano, Italy

Phone: + 3902390141 , Fax: + 390239014744

luisa.diomede@marionegri.it

Supporting information available online at

http://www.thieme-connect.de/products

\section{ABSTRACT}

Magnolia officinalis and Magnolia obovata bark extracts have been used for thousands of years in Chinese and Japanese traditional medicines and are still widely employed as herbal preparations for their sedative, antioxidant, anti-inflammatory, antibiotic, and antispastic effects. Neolignans, particularly magnolol and honokiol, are the main substances responsible for the beneficial properties of the magnolia bark extract (MBE). The content of magnolol and honokiol in MBE depends on different factors, including the Magnolia plant species, the area of origin, the part of the plant employed, and the method used to prepare the extract. The biological and pharmacological activities of magnolol and honokiol have been extensively investigated. Here we review the safety and toxicological properties of magnolol and honokiol as pure substances or as components of concentrated MBE, including the potential side-effects in humans after oral intake. In vitro and in vivo genotoxicity studies indicated that concentrated MBE has no mutagenic and genotoxic potential, while a subchronic study performed according to OECD (Organisation for Economic Co-operation and Development) guidelines established a no adverse effect level for concentrated MBE $>240 \mathrm{mg} / \mathrm{kg}$ b.w/d. Similar to other dietary polyphenols, magnolol and honokiol are subject to glucuronidation, and despite a relatively quick clearance, an interaction with pharmaceutical active principles or other herbal constituents cannot be excluded. However, intervention trials employing concentrated MBE for up to $1 \mathrm{y}$ did not report adverse effects. In conclusion, over the recent years different food safety authorities evaluated magnolol and honokiol and considered them safe.
\end{abstract}

\section{Introduction}

MBE has been used for thousands of years in traditional Chinese, Japanese, and Korean medicine and has recently been introduced as an active ingredient in food supplements and cosmetics. Among the different magnolia species, Magnolia officinalis Rehder \& E. H.Wilson (Magnoliaceae, commonly called Hou Po magnolia or magnolia bark) and Magnolia obovata Thunb are the ones most often used for these purposes. Their bark and flower extracts are used alone or combined with other herbal-derived compounds as remedies for gastrointestinal disorders, anxiety, and allergies [1, 2]. The other pharmacological activities described for MBE and its major constituents include sedative, antioxidant, anti-inflammatory, antibiotic, and antispastic effects [3]. Cosmetics contain- ing M. officinalis bark extract have recently appeared on the market, although their anti-aging effects have not been scientifically proved. For its digestive and rebalancing activity on the oral microbiome, various different European national institutions have included $M$. officinalis (flos, cortex) in lists of herbal preparations suitable for inclusion in food supplements [3].

Neolignans, particularly magnolol and honokiol ( $\bullet$ Fig. 1 ), are reported to be the compounds mainly responsible for MBE's beneficial properties, and their biological and pharmacological activities have been extensively investigated $[2,4-6]$. The aim of this review is to have a critical look to the safety and toxicological properties of magnolol and honokiol, as pure substances or as components of concentrated MBE containing more than $90 \%$ of total neolignans, on the basis of a critical, systematic analysis of 


\begin{tabular}{|c|c|}
\hline \multicolumn{2}{|c|}{ ABBREVIATIONS } \\
\hline CYP & cytochrome P450 \\
\hline CYP1A & $\begin{array}{l}\text { cytochrome P450, family } 1 \text {, subfamily A, } \\
\text { polypeptide }\end{array}$ \\
\hline HIM & human intestinal microsomes \\
\hline HLM & human liver microsomes \\
\hline MBE & magnolia bark extract \\
\hline NOAEL & no adverse effect level \\
\hline PICOS & $\begin{array}{l}\text { patient, problem or population intervention, } \\
\text { comparison, control or comparator, outcome } \\
\text { with added qualitative search terms }\end{array}$ \\
\hline PPAR $y$ & $\begin{array}{l}\text { peroxisome proliferator-activated receptor } \\
\text { gamma }\end{array}$ \\
\hline PRISMA & $\begin{array}{l}\text { preferred reporting items for systematic reviews } \\
\text { and meta-analyses }\end{array}$ \\
\hline RTECS & Registry of Toxic Effects of Chemical Substances \\
\hline RXR & retinoic $X$ receptor \\
\hline SULT & sulfotransferase \\
\hline $\mathrm{T}_{1 / 2}$ & half-life \\
\hline UDP & uridine diphosphate \\
\hline UGT & glucuronosyltransferase \\
\hline
\end{tabular}

the literature. To retrieve all the pertinent toxicology evidence, we applied the PICOS conceptual framework and the applicable features of the PRISMA statement $[7,8]$ to a structured literature search using a multidatabase platform. The search was done on May 25, 2017, with a global geographical coverage and time limits from the year 1910 to the date of the search. It involved the following databases: AdisInsight Safety, Allied \& Complementary Medicine, Biosis Toxicology, Embase, Global Health, International Pharmaceutical Abstracts, Medline, RTECS. After applying preselected inclusion and exclusion criteria, three authors reviewed each article for inclusion or exclusion to reach consensus, and 44 original articles were deemed pertinent for inclusion in the systematic review ( $\triangleright$ Fig. 2). Additional details on the bibliographic strategy are provided as Supporting Information.

\section{Magnolol and Honokiol Content in MBE}

The content of magnolol and honokiol in the magnolia crude extract is a key feature of the quality of MBE and can vary by more than 10 times depending on various factors, including the Magnolia species (officinalis or obovata) employed for the preparation, the part of the plant used, and the method of extraction [2,915]. Similarly, the content of the other lignans such as 4-O-methyl-honokiol and obovatol can vary; this last may even be absent in a $M$. officinalis extract ( $\vee$ Table 1 ). The area of origin can also markedly affect the phenolic content of the extract, such as quercetin and cyaniding, reflecting differences in climatic conditions and environmental biodiversity in the different regions of China where magnolia trees are grown ( $\bullet$ Fig. 3). Plantations of $M$. officinalis of the same age but from different Chinese regions, all at an altitude of around 1000 meters, had total magnolol plus hono-
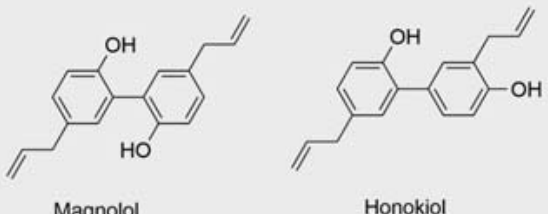

Honokiol

- Fig. 1 Chemical structures of magnolol and honokiol.

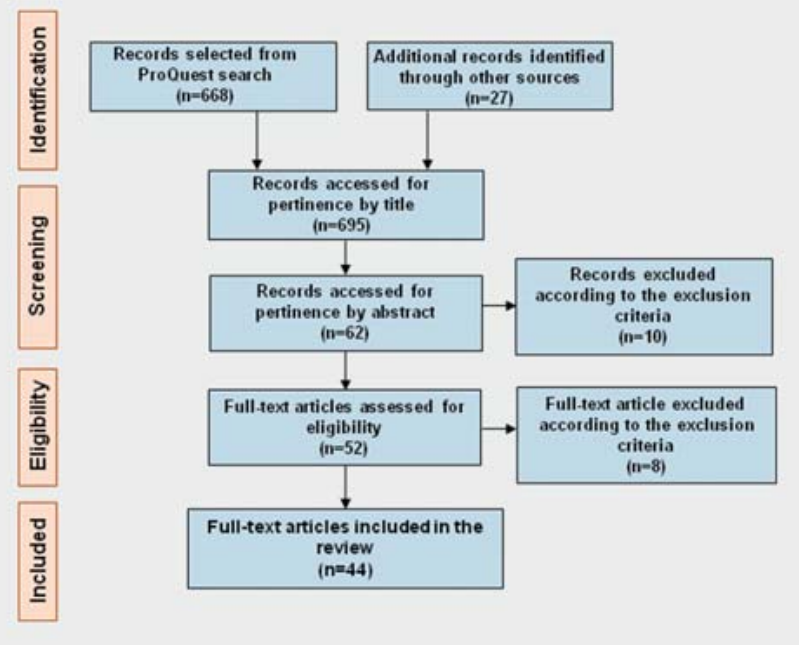

- Fig. 2 Flow diagram depicting the systematic review strategy.

- Table 1 Neolignans content in crude ethanolic or methanolic MBEs from different magnolia species.

\begin{tabular}{|l|l|l|}
\hline \multirow{2}{*}{ Neolignans } & \multicolumn{2}{|c|}{ Neolignans content ${ }^{\mathrm{a}}$ (\% of total weight) } \\
\hline M. obovata & $\mathbf{M}$. officinalis \\
\hline Magnolol & $0.78-7.65$ & $1.00-1.25$ \\
\hline Honokiol & $0.55-1.25$ & $0.17-1.81$ \\
\hline 4-O-methyl-honokiol & $0.01-0.21$ & $0.0003-1.24$ \\
\hline Obovatol & $0.01-0.33$ & not detectable \\
\hline $\begin{array}{l}\text { a Data represent the minimum and maximal values, as reported by Lee } \\
\text { et al., } 2011[2] .\end{array}$ \\
\hline
\end{tabular}

kiol concentrations in the bark varying by a factor of about 10 when samples from the West Hubei were compared to samples from Mount Lushan ( $\triangleright$ Fig. 3) [11]. The concentrations of magnolol and honokiol, and their ratios, in extracts from the trunks of Magnolia officinalis var. biloba trees grown in the same Zhejiang region also differ ( $\triangleright$ Table 2 ). The quality of the extract is also influenced by the altitude of the cultivar ( $\triangleright$ Fig. 3 ) and by the part of the plant collected to prepare the bark: trunk, branches, or root $[2,10,11,16]$. Roots seem to contain the highest concentrations 
of magnolol and honokiol $(87-96 \mathrm{mg} / \mathrm{g}$ of bark for each neolignan) ( $\triangleright$ Table 2$)[10,16]$. Considering all the influencing factors, the concentrations of the two neolignans in the bark can differ even several hundred-fold, ranging for honokiol from $0.07 \mathrm{mg} / \mathrm{g}$ to $96.51 \mathrm{mg} / \mathrm{g}$, and for magnolol from $0.05 \mathrm{mg} / \mathrm{g}$ to $91.91 \mathrm{mg} / \mathrm{g}$ [16]. Consequently, the content of total neolignans in the extracts may be different, too, as well as the ratio between the magnolol and honokiol concentrations, which can range from as little as 0.42 to as much as 12 ( $\vee$ Table 2 ). The age of the bark influences the content of neolignans, too. The percentages of magnolol and honokiol in the extract prepared from the trunk of a M. officinalis tree change with its age, peaking when the plant is $27 \mathrm{y}$ old [17]. Last but not least, different methods can be employed for the extraction of neolignans from ground dried magnolia bark. These are mainly organic and/or aqueous extractions, affecting the recovery of honokiol and magnolol. Sonication, agitation, maceration, or supercritical extraction at variable temperatures for different times (from a few minutes up to $24 \mathrm{~h}$ ) may be employed to optimize the extraction [18]. This results in widely differing concentrations of magnolol and honokiol in $M$. officinalis bark crude extracts prepared by different suppliers ( $\triangleright$ Table 3 ). From these data we can infer that similar variability is likely for the rest of the extract, whose components are often not reported but can contribute to the MBE activity. This is the case of essential oils, mainly $\beta$-eudesmol and $\alpha$ - and $\beta$-pinenes, suggested to exert pharmacological effects on the nervous system, and phenolic and polyphenolic compounds that alter microbial cell permeability and permit the loss of macromolecules thus exerting an antimicrobial activity [3]. For this reason, in this review we focused only on studies using pure magnolol or honokiol and extracts containing more than $90 \%$ of total neolignans.

\section{Mutagenicity and Genotoxicity}

Investigations of the potential mutagenic and genotoxic properties of magnolol and honokiol employed only MBE and not single purified compounds ( $\triangleright$ Table 4 ). No mutagenic activity was observed with the Ames test on four bacterial strains of Salmonella typhimurium (TA98, TA100, TA1535 and TA1537) and a strain of Escherichia coli (WP2 uvrA) treated with MBE containing $94 \%$ of magnolol and $1.5 \%$ of honokiol [19]. Results were also negative from in vitro genotoxicity studies on Chinese hamster ovarian carcinoma CHO cells and Chinese hamster lung fibroblasts (V79 cells) treated with a magnolia extract containing $92.5 \%$ of magnolol and $1.5 \%$ of honokiol, with or without metabolic activation [20]. A more recent study investigated the genotoxic effect of an aqueous extract of $M$. officinalis employing human fetal small intestinal epithelium noncancerous cells, widely used to study the biological effects of food or medicines. The MBE was analyzed by thin-layer chromatography according to the European Pharmacopeia 8.4 monographs and indicated that the presence of magnolol and honokiol was in line with the European Pharmacopeia description and that only traces of these two neolignans were present in the decoction [21]. However, we excluded this study from the pool of pertinent studies, since it did not focus on magnolol, honokiol, or concentrated extracts containing $>90 \%$ of the two neolignans. Nevertheless, we give a brief report here for the sake of complete-

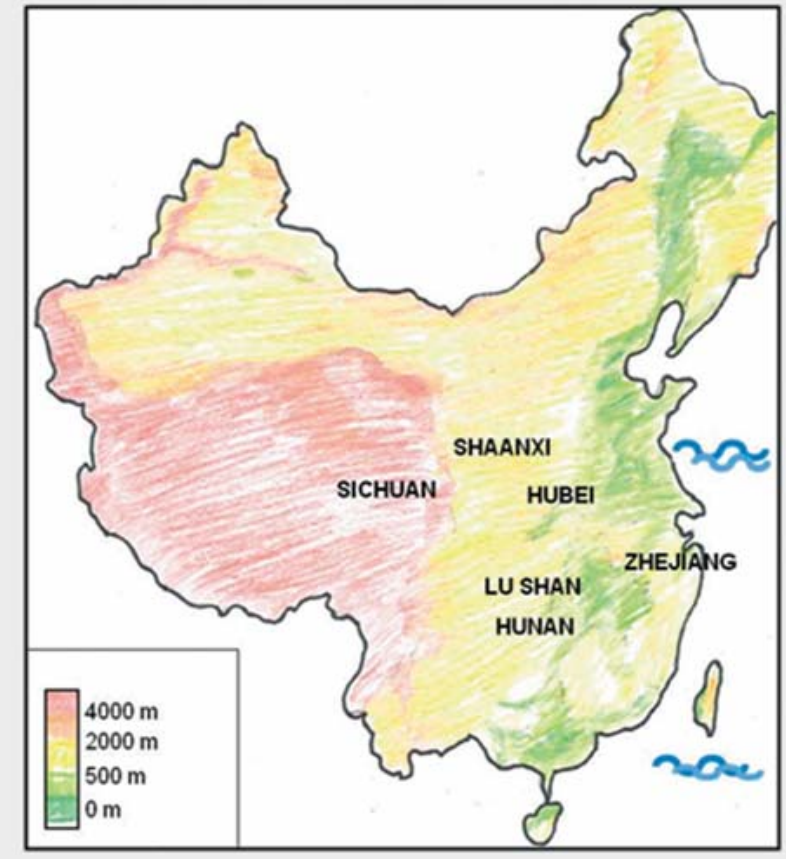

- Fig. 3 Map of China showing the areas with the main Magnolia plantations.

ness. Cells were exposed to a dose of extract in line with the estimated concentration of the plant found in the small intestine after ingestion of slimming pills containing magnolia ( 1-2 mg/ $\mathrm{mL}$ ). Phosphorylation of the serine 139 residue of histone $\gamma$ $\mathrm{H} 2 \mathrm{AX}$, a biomarker of either DNA damage or DNA repair, was determined by two different methods: immunofluorescence and whole-cell ELISA. Immunofluorescence indicated that $M$. officinalis aqueous extract could cause DNA damage, since it significantly increased $\gamma-\mathrm{H} 2 \mathrm{AX}$ foci, whereas the extract showed no genotoxicity according to the ELISA test. The unexpected possible DNA effect of the $M$. officinalis extract may be due to the highly sensitive test response to genetic insults as well as to the presence of some contaminants in the extract such as alkaloids, which were detected in the lyophilized extract used in the test but not in the raw material extract [21]. These results underline the need for further investigation on the magnolol and honokiol pure compounds in the MBE and contaminants of the extracts to identify the causative agent of the increase of $\mathrm{y}$-H2AX foci.

At the same time, the safety of Magnolia was supported by in vivo studies indicating the absence of any genotoxic potential. Swiss albino CD-1 mice (male and female, 7-9 wk old) were treated for $14 \mathrm{~d}$ with increasing oral doses $(625-2500 \mathrm{mg} / \mathrm{kg}$ b.w.) of an extract containing $94 \%$ magnolol and $1.5 \%$ honokiol ( $\triangleright$ Table 4). To assess cytogenetic damage, erythrocytes were isolated from the femoral bone marrow and the micronuclei test was done according to OECD guidelines. There were no significant changes, at any of the doses, in the proportions of immature to total erythrocytes or increase in the number of micronucleated polychromatic erythrocytes [19]. Moreover, data obtained in vitro 
- Table 2 Neolignans content in bark of trunks, branches, and roots of various plant interspecies from different China regions ${ }^{\mathrm{a}}$.

\begin{tabular}{|c|c|c|c|c|c|}
\hline Region & Magnolia species & Part of the plant & Honokiol (mg/g) & Magnolol (mg/g) & Magnolol/honokiol \\
\hline Mianyang, Sichuan & officinalis & \multirow[t]{15}{*}{ trunk } & 6.05 & 9.34 & 1.54 \\
\hline Yinshan, Hubei & officinalis & & 0.08 & 0.05 & 0.62 \\
\hline Hanzhong, Shaanxi & officinalis & & 2.69 & 4.54 & 1.69 \\
\hline Sichuan & officinalis & & 0.70 & 5.99 & 8.56 \\
\hline Huaihua, Hunan & officinalis & & 4.60 & 5.85 & 1.27 \\
\hline Sichuan & officinalis & & 29.68 & 22.92 & 0.77 \\
\hline Zhejiang & officinalis & & 35.28 & 14.83 & 0.42 \\
\hline Enshi, Hubei & officinalis & & 0.07 & 0.84 & 12.00 \\
\hline Xupu, Hunan & officinalis & & 2.40 & 25.10 & 10.46 \\
\hline Shuangpai, Hunan & officinalis & & 0.38 & 0.25 & 0.66 \\
\hline Jingzhou, Hubei & officinalis var. biloba & & 8.80 & 17.94 & 2.04 \\
\hline Nan, Hunan & officinalis var. biloba & & 3.37 & 9.37 & 2.78 \\
\hline Anhua, Hunan & officinalis var. biloba & & 13.12 & 18.97 & 1.44 \\
\hline Ruanlin, Hunan & officinalis var. biloba & & 18.37 & 31.94 & 1.74 \\
\hline Zhejiang & officinalis var. biloba & & 3.18 & 25.13 & 7.90 \\
\hline Xupu, Hunan & officinalis & branches & 6.64 & 24.00 & 3.61 \\
\hline Yunaling, Hunan & officinalis & \multirow[t]{2}{*}{ roots } & 96.51 & 90.52 & 0.94 \\
\hline Xiangxi, Hunan & officinalis & & 87.56 & 91.91 & 1.05 \\
\hline
\end{tabular}

and in animal models indicated that not only the magnolia extract have no mutagenic and genotoxic effect, but it even showed antimutagenic activity $[2,22,23]$. In particular, magnolol and honokiol inhibited UV-induced mutations in S. typhimurium TA102 by scavenging of $\mathrm{OH}$ [24]. Ames tests performed on S. typhimurium TA98 and TA100 also showed that magnolol strongly inhibited mutagenicity induced by indirect mutagens 2-amino-3-methylimidazo[4,5-f]quinoline, 2-aminodipyrido[1,2-a:3',2-D]imidazole, benzo(a)pyrene, 2-aminoanthracene and 7,12-dimethylbenz[a] anthracene through the suppression of CYP1A1 and CYP1A2 activity [25]. In mice, magnolol exerted an in vivo antimutagenic effect against clastogenicity induced by benzo(a)pyrene, evaluated using the micronucleus test, and the DNA damage-induced by $X$-ray irradiation [25]. These findings indicated that magnolia extracts containing a concentration of neolignans $>90 \%$ can be classified as safe.

\section{Metabolism}

To fully understand the mechanism of action of magnolol and honokiol and their potential toxic effects, it is very important to clarify their metabolism.

Magnolol's metabolism has been widely investigated, showing that it can be extensively metabolized by tissues and intestinal bacterial enzymes to hydrogenated and hydroxyl derivatives, glucuronides, and sulfates ( $\bullet$ Table 5 ). After oral doses of [ring- ${ }^{14} \mathrm{C}$ ] magnolol, a total of $65 \%$ of the radioactivity dose was recovered in the feces and $11 \%$ in the urine after $24 \mathrm{~h}$. The main fecal derivatives of oral magnolol in rats are magnolol and a series of metab-
- Table 3 Magnolol and honokiol contents in aqueous magnolia bark crude extracts from different suppliers.

\begin{tabular}{|l|l|l|l|}
\hline Supplier & $\begin{array}{l}\text { Honokiola } \\
\mathbf{( m g / g )}\end{array}$ & $\begin{array}{l}\text { Magnolola } \\
\mathbf{( m g / g )}\end{array}$ & $\begin{array}{c}\text { Magnolol/ } \\
\text { honokiol }^{\mathbf{a}}\end{array}$ \\
\hline 1 & 1.6 & 15.1 & 9.4 \\
\hline 2 & 1.2 & 1.6 & 1.3 \\
\hline 3 & 1.0 & 0.5 & 0.5 \\
\hline 4 & 6.6 & 5.7 & 0.9 \\
\hline 5 & 0.2 & 1.0 & 5.0 \\
\hline 6 & 0.6 & 0.8 & 1.3 \\
\hline a Each data is the mean of four values, as reported by Lee et al., 2007 \\
\hline [18].
\end{tabular}

olites in free forms (tetrahydromagnolol and trans-isomagnolol), which account for more than $90 \%$ of the administered dose; only $6 \%$ were glucuronides and sulfates, the latter being abundant in the bile [26]. The magnolol metabolites tetrahydromagnolol and trans-isomagnolol tended to increase after repeated doses, suggesting that their formation is associated with the induction of metabolic enzymes in the animal tissues and/or intestinal bacteria [26].

In view of the structural similarity of honokiol and magnolol, it was assumed that the two compounds are metabolized similarly $[26,27]$ ( $\triangleright$ Table 5). Honokiol, like magnolol, can be extensively metabolized in rats [28-31]. Studies in vitro using human liver mi- 
- Table 4 Studies investigating the mutagenic and genotoxic properties of magnolol and honokiol.

\begin{tabular}{|c|c|c|c|}
\hline Reference & Assay & Treatment & Results \\
\hline \multirow[t]{2}{*}{ [19] } & $\begin{array}{l}\text { Bacterial reverse } \\
\text { mutation assay }\end{array}$ & $\begin{array}{l}\text { S. typhimurium (TA98, TA100, TA1535 and TA1537 strains) and } \\
\text { E. coli (WP2 uvrA strain) were treated with } 18.75-300 \mu \mathrm{g} / \text { plate } \\
\text { MBE }(94 \% \text { magnolol and } 1.5 \% \text { honokiol) } \pm \text { metabolic activation for } \\
48-72 \mathrm{~h} \text { at } 37^{\circ} \mathrm{C}\end{array}$ & $\begin{array}{l}\text { No mutagenic activity at all the } \\
\text { tested doses }\end{array}$ \\
\hline & Micronucleus test & $\begin{array}{l}\text { Swiss albino male and female CD-1 mice were orally treated for } \\
14 \mathrm{~d} \text { with } 625-2500 \mathrm{mg} / \mathrm{kg} \text { b. w. of MBE ( } 94 \% \text { magnolol and } 1.5 \% \\
\text { honokiol) }\end{array}$ & $\begin{array}{l}\text { No effect on the proportion of } \\
\text { immature to total erythrocytes nor } \\
\text { on the number of micronucleated } \\
\text { polychromatic erythrocytes }\end{array}$ \\
\hline \multirow[t]{2}{*}{ [20] } & \multirow[t]{2}{*}{$\begin{array}{l}\text { Chromosomal } \\
\text { aberration assays }\end{array}$} & $\begin{array}{l}\mathrm{CHO} \text { cells treated with } 0-30 \mu \mathrm{g} / \mathrm{mL} \text { of } \mathrm{MBE}(92.5 \% \text { magnolol and } \\
1.5 \% \text { honokiol }) \pm \text { metabolic activation for } 3-18 \mathrm{~h}\end{array}$ & No chromosomal aberrations \\
\hline & & $\begin{array}{l}\text { V79 cells treated with }>52-59 \mu \mathrm{g} / \mathrm{mL} \text { of } \mathrm{MBE}(92.5 \% \text { magnolol } \\
\text { and } 1.5 \% \text { honokiol }) \pm \text { metabolic activation for } 6-24 \mathrm{~h}\end{array}$ & No chromosomal aberrations \\
\hline
\end{tabular}

crosomes, and ex vivo in microsomes prepared from livers isolated from rats and then perfused with $10 \mu \mathrm{M}$ honokiol [28], indicated that its metabolism resulted in the formation of two main metabolites, honokiol monoglucuronide and honokiol monosulfate, suggesting the main contributions of glucuronidation and sulfation to clearance. A recent in vitro study identified the metabolic profile of honokiol in different animal species and the enzymes involved in its derivatization. The neolignan was extensively metabolized by extrahepatic and hepatic pathways, producing glucuronic derivatives as main compounds and other 32 metabolites after sulfation and oxidation [32].

Human metabolism usually employs conjugation with glucuronic acid in order to increase compounds' hydrophilic properties, facilitating their excretion. This pattern of transformation, found in both magnolol and honokiol, has been described for other polyphenols as well, such as tea catechins [33] and resveratrol [34].

\section{Absorption and Biodistribution}

Different studies have examined the bioavailability of magnolol and honokiol administered by different routes ( $\triangleright$ Table 6$)$. After intravenous (i.v.) injection of magnolol and honokiol (2-10 mg/ $\mathrm{kg}$ b.w.) to Sprague-Dawley rats the two compounds had comparable pharmacokinetic profiles $[35,36]$. The $\mathrm{T}_{1 / 2}$ (i.e., the time needed to halve the initial circulating drug concentration) of both compounds was not affected by the dose. As shown in $>$ Table 7 , the $T_{1 / 2}$ of magnolol administered at the dose of 2,5 , and $10 \mathrm{mg} /$ $\mathrm{kg}$ b. w. was respectively $54.15 \mathrm{~min}, 49.05 \mathrm{~min}$, and $49.58 \mathrm{~min}$ and the $T_{1 / 2}$ honokiol was $49.22 \mathrm{~min}$ when administered at $5 \mathrm{mg} / \mathrm{kg}$ b.w. and $56.24 \mathrm{~min}$ at the dose of $10 \mathrm{mg} / \mathrm{kg}$ b.w. [35, 36]. Pharmacokinetics and bioavailability studies have also been reported in rats given i. v. a higher dose of magnolol $(20 \mathrm{mg} / \mathrm{kg}$ b. w.). The serum and tissue concentrations of magnolol in the free form were determined, together with magnolol glucuronides and sulfates/glucuronides, to gain a picture of the metabolism. It was observed that magnolol was immediately metabolized by the liver and that magnolol glucuronides were the main conjugates detected in the blood [37].

Only one study examined the fate of magnolol injected intraperitoneally (i. p.) [26]. Respectively $52 \%$ and $24 \%$ of the radioac- tive ${ }^{14} \mathrm{C}$-magnolol administered was excreted in the feces and urine within $24 \mathrm{~h}$, indicating rapid elimination.

Numerous studies have investigated the oral bioavailability of magnolol. A single oral dose of radioactive ${ }^{14} \mathrm{C}$-magnolol to rats resulted in two peaks of radioactivity in blood, the first after $15 \mathrm{~min}$, and the second $8 \mathrm{~h}$ later, suggesting enterohepatic circulation of magnolol and its metabolites [26]. The circulating radioactivity returned to baseline within $48 \mathrm{~h}$. Radioactivity distributed mostly in the gastrointestinal tract and liver, reaching $11 \%$ of the dose after $15 \mathrm{~min}$, and was found also in kidney, pancreas, and lung. Similarly to what happens after i. p. injection, oral magnolol was mainly excreted in the feces ( $65 \%$ of the radioactivity) and the urine ( $11 \%$ of the radioactivity) within the first $24 \mathrm{~h}$ [26], suggesting that magnolol is rapidly removed from the body. Six days after the dose, more than $80 \%$ of the administered radioactivity had been excreted. Various isomers and metabolites of magnolol were also detected in urine and fecal samples. In particular, the presence of magnolol glucuronidated derivatives in bile or feces indicates that bacteria and enzymes in the animal intestines are able to metabolize magnolol.

In a similar study, rats were given nonradioactive magnolol orally at the dose of $20 \mathrm{mg} / \mathrm{kg}$ b. w. [38]. Thirty minutes later approximately $90 \%$ of magnolol had already been metabolized and transformed to the glucuronidated form, while total bioavailability of magnolol was less than $10 \%$ [38]. These authors reported that in rats given $20 \mathrm{mg} / \mathrm{kg}$ b. w. orally of magnolol the maximal circulating concentration was reached after $1 \mathrm{~h}(0.16 \pm 0.023 \mu \mathrm{g} /$ $\mathrm{mL}$ ) and remained constant for about $6 \mathrm{~h}$, with a subsequent linear decrease within $16 \mathrm{~h}[1,38]$. Bioavailability was similar when magnolol was given orally at the higher dose of $50 \mathrm{mg} / \mathrm{kg} \mathrm{b.w.}$ [37].

To clarify the steady-state pharmacokinetics of magnolol, rats were orally given $50 \mathrm{mg} / \mathrm{kg}$ b. w. of magnolol three times a day for seven doses [37]. The serum concentration of magnolol was lower and more stable than after a single dose, while the magnolol sulfates/glucuronides were much higher, with three peaks at 15, 60, and $240 \mathrm{~min}$, indicating the enterohepatic circulation of magnolol conjugates [26]. These results show that repeated doses result in a temporary accumulation of magnolol sulfates/glucuronides but not free magnolol. 
- Table 5 Studies investigating the metabolism of magnolol and honokiol.

\begin{tabular}{|c|c|c|}
\hline Reference & Study & Results \\
\hline [52] & $\begin{array}{l}\text { Magnolol }(0-250 \mu \mathrm{M}) \text { was incubated with HLM or HIM or } \\
\text { recombinant UGT enzymes }(0.01-0.1 \mathrm{mg} / \mathrm{L}) \text { for } 20 \text { min at } \\
37^{\circ} \mathrm{C}\end{array}$ & $\begin{array}{l}\text { Magnolol inhibited the activity of multiple UGT enzymatic isoforms in } \\
\text { microsomes }\end{array}$ \\
\hline [51] & $\begin{array}{l}\text { Magnolol }(0.1-10 \mu \mathrm{M}) \text { was incubated with HLM or UGT } \\
\text { enzymes }(10-2000 \mu \mathrm{M}) \text { for } 20 \mathrm{~min} \text { at } 37^{\circ} \mathrm{C}\end{array}$ & $\begin{array}{l}\text { Magnolol, at concentrations lower than those possibly reached in hu- } \\
\text { man gut lumen and blood, inhibited the activity of different UGT iso- } \\
\text { forms and abolished propofol glucuronidation activity in microsomes }\end{array}$ \\
\hline [53] & Honokiol $(0.01-200 \mu \mathrm{M})$ was incubated with $\mathrm{HLM}$ at $37^{\circ} \mathrm{C}$ & $\begin{array}{l}\text { Honokiol inhibited the activity of different CYP and UGT enzymes in a } \\
\text { dose-dependent manner }\end{array}$ \\
\hline [54] & $\begin{array}{l}\text { Liver microsomes from Swiss-Hauschka mice, Sprague- } \\
\text { Dawley rats, Chinese Bama pigs or Cynomolgus macaque } \\
\text { were incubated with propofol alone or together with } \\
10 \mu \mathrm{M} \text { magnolol }\end{array}$ & $\begin{array}{l}\text { Magnolol decreased the propofol glucuronidation by liver microsomes } \\
\text { from pigs or monkeys of } 25-26 \% \text { and from mice or rats of } 70-78 \%\end{array}$ \\
\hline [56] & $\begin{array}{l}\text { Microsomes from liver of male Wistar rats or HLM were } \\
\text { incubated with magnolol or honokiol (10.0-56.2 } \mu \mathrm{M})\end{array}$ & $\begin{array}{l}\text { Magnolol and honokiol showed no inhibition or weak to moderate inhi- } \\
\text { bition of CYP isoforms. No significant metabolic interaction occurred } \\
\text { when magnolol and honokiol were co-administered with drugs acting } \\
\text { as substrate for CYP isoforms }\end{array}$ \\
\hline \multirow[t]{2}{*}{ [32] } & $\begin{array}{l}\text { Hepatocytes from mouse, rat, dog, monkey, and human } \\
\text { were treated with } 20 \mu \mathrm{M} \text { honokiol for } 0-120 \text { min at } 37^{\circ} \mathrm{C}\end{array}$ & Honokiol was extensively metabolized in hepatocytes \\
\hline & $2 \mu \mathrm{M}$ honokiol was incubated with UGT and SULT isoforms & $\begin{array}{l}\text { Multiple UGT isoforms were involved in the glucuronidation of honokiol. } \\
\text { Different SULT isoforms were responsible for formation of honokiol } \\
\text { sulfates }\end{array}$ \\
\hline [55] & $\begin{array}{l}\text { HLM, HIM, or microsomes from human kidney were } \\
\text { incubated with propofol alone or together with magnolol }\end{array}$ & $\begin{array}{l}\text { Magnolol potently inhibited propofol glucuronidation in HLM and } \\
\text { human kidney microsomes but not in HIM }\end{array}$ \\
\hline \multirow[t]{2}{*}{ [28] } & $\begin{array}{l}\text { HLM }(50 \mu \mathrm{g} \text { of protein) were incubated with honokiol for } \\
20 \text { min at } 37^{\circ} \mathrm{C} \text { in the presence of uridine 5-diphospho- } \\
\text { glucuronic acid and 3-phosphoadenosine-5-phospho- } \\
\text { sulfate }\end{array}$ & $\begin{array}{l}\text { Glucuronidation (UGTs isoenzymes) and sulfation (SULTs isoenzymes) } \\
\text { were the main metabolic pathways for honokiol }\end{array}$ \\
\hline & $\begin{array}{l}\text { Male Wistar rat livers were perfused with } 10 \mu \mathrm{M} \text { honokiol } \\
\text { for } 90 \mathrm{~min} \text { and microsomes were isolated }\end{array}$ & $\begin{array}{l}\text { P450-mediated oxidation by liver microsomes did not contribute to the } \\
\text { metabolism of honokiol }\end{array}$ \\
\hline [26] & $\begin{array}{l}\text { Single or repeated doses of }\left[{ }^{14} \mathrm{C}\right] \text { magnolol were orally } \\
\text { or i. p. administered to male Wistar rats }\end{array}$ & $\begin{array}{l}\text { A single oral dose of }\left[{ }^{14} \mathrm{C}\right] \mathrm{magnolol} \text { resulted in two peaks of radioactivity } \\
\text { in blood ( } 15 \mathrm{~min} \text { and } 8 \mathrm{~h} \text { after the administration) indicating the enter- } \\
\text { ohepatic circulation of magnolol and its metabolites. Radioactivity } \\
\text { mainly distributed in the gastrointestinal tract and liver, but also in kid- } \\
\text { ney, pancreas, and lung. } \\
\text { A similar excretion dynamic was observed after a single oral and i. p. } \\
\text { administration. Within } 12-24 \mathrm{~h} \text { more than } 72 \% \text { of magnolol was } \\
\text { excreted in feces and } 24 \% \text { in urine. } \\
\text { Repeated oral doses resulted in the accumulation of magnolol sulfates/ } \\
\text { glucuronides but not free magnolol }\end{array}$ \\
\hline [27] & $\begin{array}{l}{\left[{ }^{14} \mathrm{C}\right] \text { magnolol }(13 \mathrm{mg} / \mathrm{kg} \text { b. w.) was administered i. v. to }} \\
\text { male Wistar rats }\end{array}$ & $\begin{array}{l}{ }^{14} \mathrm{C} \text {-magnolol reached the maximal blood concentration } 1 \mathrm{~h} \text { after the } \\
\text { administration and disappeared within } 4 \mathrm{~h} \text {. Biliary levels of radioactivity } \\
\text { start to increase } 30 \mathrm{~min} \text { after administration and reached the maximal } \\
\text { concentration of } 1.3 \mu \mathrm{mol} / \mathrm{mL} 4 \mathrm{~h} \text { after. At this time-point radioactivity } \\
\text { was detected also in the lungs, liver and kidneys. Minor proportion of } \\
\text { magnolol was excreted through the gastrointestinal wall }\end{array}$ \\
\hline
\end{tabular}

No indications on the pharmacokinetic profile of magnolol in humans are available. Only one study employing an extract containing less than $90 \%$ of total neolignans was performed. Although it did not meet the inclusion criteria, it was still considered in this review. Seven healthy subjects and ten asthmatic patients were treated with $5 \mathrm{~g} / \mathrm{d}$ of Saiboku-To, the $M$. officinalis bark extract used in China as herbal medicine for bronchial asthma, corresponding to $2.1 \mathrm{mg} / \mathrm{d}$ of magnolol [39]. The urinary excretion profile of magnolol was reported. In the asthmatic patients and the healthy subjects $10 \%$ of magnolol was excreted in the urine within $9 \mathrm{~h}$ and about $95 \%$ of urinary magnolol was glucuronidated [39]. These data, comparable to findings from animal models [26], suggest that magnolol can be rapidly excreted in humans, too.

Little information is available so far on the pharmacokinetics and distribution of honokiol $[40,41]$. A single oral dose of honokiol $(40 \mathrm{mg} / \mathrm{kg}$ b.w.) in rats was rapidly absorbed, reaching its peak plasma concentration within $20 \mathrm{~min}$. It is also rapidly metabolized to mono-glucuronidated honokiol, and slowly eliminated $\left(T_{1 / 2}=290.4 \mathrm{~min}\right)$ [40]. Honokiol rapidly distributed into organs 
- Table 6 Pharmacokinetic and pharmacodynamic studies.

\begin{tabular}{|c|c|c|}
\hline Reference & Treatment & Results \\
\hline [26] & $\begin{array}{l}\text { Single or repeated doses of }\left[{ }^{14} \mathrm{C}\right] \text { magnolol were } \\
\text { orally or i. p. administered to male Wistar rats }\end{array}$ & $\begin{array}{l}\text { Radioactivity mainly distributed in the gastrointestinal tract and liver, but also } \\
\text { in kidney, pancreas and lung. A similar excretion dynamic was observed after a } \\
\text { single oral and i. p. administration. Within } 12-24 \mathrm{~h} \text { more than } 72 \% \text { of magnolol } \\
\text { was excreted in feces and } 24 \% \text { in urine. } \\
\text { Repeated oral doses resulted in the accumulation of magnolol sulfates/glucu- } \\
\text { ronides but not free magnolol }\end{array}$ \\
\hline [38] & $\begin{array}{l}\text { Magnolol was orally administered at the dose of } \\
20 \mathrm{mg} / \mathrm{kg} \text { b. w. to male Sprague-Dawley rats }\end{array}$ & $\begin{array}{l}\text { Thirty minutes after the administration the concentration of glucoronidated } \\
\text { magnolol and free magnolol were } 1.79 \mu \mathrm{g} / \mathrm{mL} \text { and } 0.16 \mu \mathrm{g} / \mathrm{mL} \text {, respectively }\end{array}$ \\
\hline [1] & $\begin{array}{l}\text { Magnolol was orally administered at } 5-100 \mathrm{mg} / \\
\mathrm{kg} / \mathrm{b} . \mathrm{w} \text {. to male Sprague-Dawley rats }\end{array}$ & $\begin{array}{l}\text { The absorption half-life was } 0.63 \mathrm{~h} \text {, the elimination half-life } 2.33 \mathrm{~h} \text {, the time of } \\
\text { maximum concentration } 1.12 \mathrm{~h} \text {, and the maximum concentration is } 0.16 \mu \mathrm{g} / \\
\mathrm{mL} \text {. Oral bioavailability was } 4-9 \% \text {. The locomotor activity, measured as indica- } \\
\text { tive of the pharmacodynamic profile, was affected starting from } 20 \mathrm{mg} / \mathrm{kg} / \\
\text { b. w. }\end{array}$ \\
\hline [35] & $\begin{array}{l}\text { Magnolol was administered i.v. at } 2-10 \mathrm{mg} / \mathrm{kg} \\
\text { b.w. to male Sprague-Dawley rats }\end{array}$ & $\begin{array}{l}\text { Increasing dosages have same half-life but increasing AUC. Magnolol distrib- } \\
\text { utes evenly in different brain regions with concentration higher than plasma }\end{array}$ \\
\hline [37] & $\begin{array}{l}\text { Magnolol was administered to male Sprague- } \\
\text { Dawley rats as a single i.v. dose } 20 \mathrm{mg} / \mathrm{kg} \text { b. w. or } \\
\text { as single or multiple oral doses }(50 \mathrm{mg} / \mathrm{kg} / \text { b. w.) }\end{array}$ & $\begin{array}{l}\text { Comparable levels of magnolol and magnolol glucuronides were found in the } \\
\text { blood after i. v. administration whereas in orally treated rats the levels of } \\
\text { magnolol glucuronides and sulfates were higher than that of free magnolol. } \\
\text { The highest concentrations were found in the liver. Magnolol was found also in } \\
\text { kidney, brain, lung, and heart }\end{array}$ \\
\hline [36] & $\begin{array}{l}\text { Honokiol was administered i.v. to male Sprague- } \\
\text { Dawley rats at the dose of } 5-10 \mathrm{mg} / \mathrm{kg} \text { b.w. }\end{array}$ & $\begin{array}{l}\text { A biphasic process consisting of a rapid distribution phase followed by a slower } \\
\text { elimination phase was observed from the plasma concentration-time curves }\end{array}$ \\
\hline [40] & $\begin{array}{l}\text { Honokiol was orally administered to male Wistar } \\
\text { rats at } 40 \mathrm{mg} / \mathrm{kg} / \mathrm{b} . \mathrm{w} \text {. }\end{array}$ & $\begin{array}{l}\text { Honokiol was rapidly absorbed reaching its maximal plasma concentration } \\
\text { within } 20 \text { min. It was rapidly metabolized to mono-glucuronidated honokiol } \\
\text { and slowly eliminated ( } T_{1 / 2}=290.4 \text { min). Honokiol rapidly distributed in liver, } \\
\text { kidney, and brain. The concentrations of honokiol and its metabolites were } \\
\text { highest in liver, followed by kidney and brain. At central level only honokiol was } \\
\text { detected indicating that its metabolites cannot cross the blood-brain barrier }\end{array}$ \\
\hline [41] & $\begin{array}{l}\text { M. officinalis cortex extract (corresponding to } \\
12.78 \mathrm{mg} / \mathrm{kg} \text { b.w. of magnolol) was administered } \\
\text { intragastrically to male Sprague-Dawley rats }\end{array}$ & $\begin{array}{l}\text { Within the first } 35 \text { min of administration, magnolol and honokiol crossed the } \\
\text { blood brain barrier and accumulated in different brain regions }\end{array}$ \\
\hline [39] & $\begin{array}{l}\text { Healthy subjects and asthmatic patients were } \\
\text { treated with } 5 \mathrm{~g} / \mathrm{d} \text { of Saiboku-To (corresponding } \\
\text { to } 2.1 \mathrm{mg} / \mathrm{d} \text { of magnolol) }\end{array}$ & $\begin{array}{l}\text { Both asthmatic patients and the healthy subjects excreted the } 10 \% \text { of admin- } \\
\text { istered magnolol in the urine within } 9 \mathrm{~h} \text {. About the } 95 \% \text { of urinary magnolol } \\
\text { were glucuronidated }\end{array}$ \\
\hline
\end{tabular}

(liver, kidney, brain) and was detected in various tissues after only $5 \mathrm{~min}$. The concentrations of honokiol and its metabolites were highest in the liver, followed by kidney and brain. At central level only honokiol was detectable, suggesting that its metabolites cannot cross the blood-brain barrier [40].

In a similar study, rats were treated with a series of extracts, containing aqueous $M$. officinalis cortex extract alone or with other herbs. The amounts of single or combined extracts were standardized to deliver a dose corresponding to $12.78 \mathrm{mg} / \mathrm{kg}$ b.w. of magnolol [41]. This dose was calculated as equivalent to the effective daily dose of the Zhi-Zi-Hou-Po decoction, one of the famous Chinese antidepressant formulas containing $M$. officinalis cortex, Gardenia jasminoides J.Ellis (Rubiaceae) and Citrus aurantium L. (Rutaceae) $[41,42]$. The extracts also contained honokiol, allowing the determination of absorption and distribution of both neolignans. Magnolol and honokiol rapidly crossed the bloodbrain barrier reaching different brain regions within the first $35 \mathrm{~min}$ after the dose [41].

In summary, the bioavailability of magnolol and honokiol seems to be limited, and after reaching the enterohepatic circula-
- Table 7 Half-life of magnolol and honokiol in rats after intravenous injection of different doses.

\begin{tabular}{|l|l|l|}
\hline $\begin{array}{l}\text { Dose } \\
\text { (mg/kg b. w.) }\end{array}$ & \multicolumn{2}{|c|}{ Half-life (minutes \pm SE) } \\
\hline 2 & $54.15 \pm 5.14$ & not determined \\
\hline 5 & $49.05 \pm 5.96$ & $49.22 \pm 6.68$ \\
\hline 10 & $49.58 \pm 6.81$ & $56.24 \pm 7.30$ \\
\hline
\end{tabular}

tion, they are both eliminated mostly with the feces and partly in urine. The absorbed fraction of neolignans, either in free form or possibly bound to serum albumin [43] or conjugated with glucuronic or sulfuric acid, can reach different target organs, from which they are rapidly eliminated. Similar pathways have been described for other polyphenols, such as tea catechins [33] and resveratrol [34]. 
- Table 8 Toxicological studies.

\begin{tabular}{|c|c|c|c|c|}
\hline Reference & Subject & Aim of the study & Treatment & Results \\
\hline \multirow[t]{3}{*}{ [80] } & $\begin{array}{l}\text { Human } \\
\text { platelets }\end{array}$ & $\begin{array}{l}\text { Effect of honokiol on } \\
\text { platelets aggregation }\end{array}$ & $\begin{array}{l}\text { Platelets were incubated with } 0.1 \text { - } \\
1.0 \mu \mathrm{M} \text { honokiol in the presence of } \\
\text { collagen }(1 \mu \mathrm{g} / \mathrm{mL}), 0.05 \mathrm{U} / \mathrm{mL} \text { of } \\
\text { thrombin, } 1 \mu \mathrm{M} U 46619 \text {, or } 60 \mu \mathrm{M} \\
\text { arachidonic acid }\end{array}$ & $\begin{array}{l}\text { Honokiol antagonized the platelet aggregation } \\
\text { induced by collagen but not by other com- } \\
\text { pounds. It did not affect platelet permeability } \\
\text { nor induce platelet cytolysis }\end{array}$ \\
\hline & $\begin{array}{l}\text { Wild-type zebra- } \\
\text { fish embryos }\end{array}$ & $\begin{array}{l}\text { Evaluation of } \\
\text { honokiol toxicity }\end{array}$ & $\begin{array}{l}\text { Zebrafish embryos were treated with } \\
1-10 \mu \mathrm{M} \text { honokiol }\end{array}$ & $\begin{array}{l}\text { Honokiol was not cytotoxic for zebrafish } \\
\text { embryos }\end{array}$ \\
\hline & Male ICR mice & $\begin{array}{l}\text { Evaluation of anti- } \\
\text { clotting potential } \\
\text { of honokiol }\end{array}$ & $\begin{array}{l}\text { Honokiol was administered i. v. to mice } \\
\text { at } 0.5 \mathrm{mg} / \mathrm{kg} \text { b. w. }\end{array}$ & $\begin{array}{l}\text { Honokiol inhibited platelet activation and } \\
\text { aggregation, and increased the time of throm- } \\
\text { botic platelet plug formation }\end{array}$ \\
\hline [47] & $\begin{array}{l}\text { Female and male } \\
\text { Kunming mice }\end{array}$ & $\begin{array}{l}\text { Effect of methanol } \\
\text { extracts of } M \text {. offi- } \\
\text { cinalis on kidney } \\
\text { functionality }\end{array}$ & $\begin{array}{l}\text { Methanolic extract of } M \text {. officinalis was } \\
\text { intragastrically administered as a single } \\
\text { dose at } 0.25 \mathrm{~g} \text { (equivalent to } 6.25 \mathrm{mg} \text { of } \\
\text { magnolol and } 2 \text { mg of honokiol) or for } 1 \text {, } \\
2 \text {, or } 3 \text { mo at the dose of } 0.25 \mathrm{~g} / \mathrm{d}\end{array}$ & $\begin{array}{l}\text { Magnolol and honokiol accumulated in serum, } \\
\text { urine and kidneys in mice treated for } 3 \text { mo. } \\
\text { Increased levels of serum creatinine, urea nitro- } \\
\text { gen and serum albumin as well as alterations of } \\
\text { the kidney ultrastructure were observed }\end{array}$ \\
\hline [49] & $\begin{array}{l}\text { Male and female } \\
\text { Sprague-Dawley } \\
\text { rats }\end{array}$ & $\begin{array}{l}\text { Short-term }(21-d) \\
\text { and sub-chronic } \\
(90-d) \text { toxicity of MBE }\end{array}$ & $\begin{array}{l}\text { Rats were exposed to diet containing } \\
60-480 \mathrm{mg} / \mathrm{kg} \text { b. w. } / \mathrm{d} \text { of MBE ( } 95.5 \% \\
\text { magnolol plus honokiol) for } 21 \mathrm{~d} \text { or } \\
60-240 \mathrm{mg} / \mathrm{kg} \text { b. w./d of MBE for } 90 \mathrm{~d}\end{array}$ & $\begin{array}{l}\text { No treatment-related macroscopic and micros- } \\
\text { copy lesions as well as any signs of toxicity were } \\
\text { observed. NOAEL for MBE was }>240 \mathrm{mg} / \mathrm{kg} \text { b. w. }\end{array}$ \\
\hline
\end{tabular}

\section{Toxicological Studies}

The potential toxicity of different formulas containing magnolia extracts has been investigated in several animal studies ( $\bullet$ Table 8). According to the National Research Institute of Chinese Medicine, MBE has low toxicity when administered orally. The oral dose that causes the death of $50 \%$ of the test animals (lethal dose $50 \%$, $\left.L D_{50}\right)$ is $>50 \mathrm{~g} / \mathrm{kg}$ b. w. When MBE was injected i. p., the $\mathrm{LD}_{50}$ was about six times lower $(8.5 \mathrm{~g} / \mathrm{kg}$ b.w.) $[2,44,45]$, although data from traditional Chinese medicine describes similar low patterns of toxicity after oral and i.p. doses [46]. A methanol extract of M. officinalis was given as a single dose of $0.25 \mathrm{~g}$ or chronically to mice for 1,2 , or $3 \mathrm{mo}$, at doses of $0.25 \mathrm{~g} / \mathrm{d}$, equivalent to $6.25 \mathrm{mg} /$ $\mathrm{d}$ magnolol and $2 \mathrm{mg} / \mathrm{d}$ honokiol [47]. There was significant accumulation of magnolol and honokiol in serum, urine, and kidneys only in mice treated for 3 mo. These effects were accompanied by increase in clinical parameters relevant to kidney function, such as serum creatinine, urea nitrogen, and serum albumin. There were also significant alterations of the kidney ultrastructure morphology in the mice treated for 3 mo-a further indication of the kidney impairment induced by chronic treatment with $M$. officinalis methanol extract.

A magnolia bark crude $50 \%$ ethanol extracts (5 or $10 \mathrm{~g} / \mathrm{kg}$ b. w.) given by esophageal intubation to male rats for $14 \mathrm{~d}$ resulted in decreases in alanine aminotransferase and creatinine and increase in blood urea nitrogen [48]. However, these last observations were based on the effects of traditional Chinese preparations of $\mathrm{MBE}$, so the precise concentrations of magnolol and honokiol are not known, thus not fitting the inclusion criteria of this review. Conversely, in a study with concentrated MBE (containing $95.5 \%$ magnolol plus honokiol), no mortality or clinical signs of toxicity, or alterations in the major organs at autopsy, were reported in animals given 625, 1250, or $2500 \mathrm{mg} \mathrm{MBE} / \mathrm{kg}$ b.w./d orally for $14 \mathrm{~d}$ [19]. The safety profile was also examined in two subchronic (21-d and 90-d) toxicity feeding studies in rats fed diets containing MBE at various concentrations [49]. This study is noteworthy because it was conducted according to the OECD Principles of Good Laboratory Practice standard procedures [50]. In the 21-d study, rats were fed $60-480 \mathrm{mg} / \mathrm{kg} \mathrm{b.} \mathrm{w./d}$, and in the $90-\mathrm{d}$ study they received $60-240 \mathrm{mg} / \mathrm{kg}$ b. w./d of MBE. No treatment-related macroscopic or microscopic lesions and no signs of toxicity were detected, confirming the safety of MBE for oral consumption [49]. From these results, the NOAEL for concentrated MBE was established at $>240 \mathrm{mg} / \mathrm{kg}$ b. w./d as an oral dose [49].

\section{Interaction with Drugs or Other Substances}

To investigate whether the consumption of products containing honokiol and magnolol can potentially result in dangerous clinical outcomes, increasing efforts have been made to assess their effects on human CYP and UGT enzymes. Magnolol and honokiol can be metabolized in humans and rats, undergoing extensive glucuronidation in the liver and intestines. The enzymes responsible for this metabolism are isoforms of UDP-UGT, which catalyze the transfer of glucuronic acid from UDP-glucuronic acid to magnolol/honokiol, making it a more soluble substrate, readily excreted by the kidney $[51,52]$. Human UGT isoforms are divided into three subfamilies (known as 1A, 2A, and 2B) based on various amino acid sequences and structures expressed in a tissue-specific manner [51]. Liver and intestine are the two most important glucuronidation sites for orally administered neolignans. It has been reported that magnolol and honokiol can potently inhibit the activity of UGT isoforms $1 \mathrm{~A} 7$ and $1 \mathrm{~A} 9$ in humans and rodents $[32,51]$. This is not a trivial matter, since UGTs exert an important protective effect against many carcinogens and drugs with side or 
even toxic effects, and their inhibition slows the clearance of drugs, thus raising their blood and tissue levels. Therefore, the inhibition of UGTs by magnolol may be a potential mechanism that enhances the toxicity of drugs or other active compounds contained in the herbal preparation [51,53].

Different liver microsomes from mice, rats, pigs, and monkeys were employed to identify the best model for studying whether the inhibition of glucuronidation by magnolol can interact with the metabolism of other drugs. In a comparison of rat and human CYP enzymes, magnolol and honokiol were tested for inhibitory activity on five pairs of the corresponding enzymes. In all the tests, the human enzymes were less affected than rat enzymes by the magnolia neolignans; honokiol was only a moderate inhibitor of human CYP1A2, while both magnolol and honokiol were classified as weak or noninhibitors of the remaining enzymes [53].

The effects of magnolol on different animal species were compared in a study with propofol, a widely used anesthetic. In rats the inhibition of glucuronidation by magnolol resulted in prolongation of the propofol anesthesia, whereas pigs and monkeys, whose metabolism is very close to humans, were much less sensitive to the UGT inhibition [54]. A subsequent in vitro study confirmed that magnolol can inhibit propofol glucuronidation by the liver and kidney microsomes, but not by intestinal microsomes [55]. These findings indicate that magnolol inhibits UGT differently in humans and animals, highlighting the difficulty of adequately modeling clinical drug interactions involving UGT inhibition.

Although the UGT expression profile is different in rats and mice from that in humans, nearly all whole-animal magnolol pharmacological studies have been conducted in these rodents. Pharmacokinetic studies in rats indicated that after oral administration, magnolol in the liver can reach the concentration of about $10 \mu \mathrm{M}$ [37]. This concentration almost completely abolished the glucuronidation of propofol by human enzymes in vitro, while only limited inhibition was observed in rats $[51,52]$. These results suggest that, when no significant inhibition of UGT is seen in laboratory animals, the potential inhibition and the corresponding toxic effects in humans may be underestimated.

The ability of magnolol and honokiol to interact with drugs has been investigated by assessing their effects on CYP enzymes. In vitro studies using human liver microsomes indicated that honokiol and magnolol inhibited the activity of different CYP1A2, CYP2C8, CYP2C9, and CYP2C19 enzymes involved in drug metabolism and hydroxylation. These two neolignans, similarly to other herb-derived compounds, may have the potential to interact pharmacologically with other co-administered drugs metabolized by CYP enzymes $[53,56]$.

It has also been reported that in vitro MBE, as well as magnolol and honokiol, can activate cannabinoid 1 and 2 receptors, which mediate analgesia, stimulate appetite, and have anti-inflammatory action [57]. These effects were also seen with magnolol's two main metabolites, isomagnolol and tetrahydromagnolol, pointing to a new potential mechanism of action for MBE and suggesting a potential synergistic effect with other molecules acting on cannabinoids receptors [57].

Magnolol has been also suggested to exert a benzodiazepinelike sleep-promoting effect by acting on the $G_{A B A_{A}}$ receptor, known to be modulated by traditional benzodiazepines as well as nonbenzodiazepine hypnotic drugs which are the first line pharmacological agents used to treat insomnia [58]. These findings suggest that the ability of magnolol to increase the effect of drugs interacting with $G_{A B A}$ receptors should not be excluded.

Honokiol, for its ability to activate RXR, is considered a natural retinoid agonist $[59,60]$. It has been recently reported to act also as agonist of PPARy, a ligand-dependent transcriptional factor member of the nuclear hormone receptor subfamily. Similar to other agonist of PPAR $y$, which are used as antidiabetic drugs, honokiol stimulated glucose uptake in vitro in 3T3-L1 adipocytes [61, 62] efficiently stimulating differentiation via multiple pathways, including RXR activation. The oral administration of honokiol at $200 \mathrm{mg} / \mathrm{kg}$ b. w. for $8 \mathrm{wk}$ lowered fasting blood glucose in type 2 diabetic mice by enhancing phosphorylation of insulin receptor $\beta$ subunit, which is critical to trigger insulin signaling pathway. In addition, it activated the downstream insulin signaling factors including the serine/threonine kinase Akt and extracellular signalregulated kinases $1 / 2$ [63]. The ability of honokiol to interact with insulin metabolism should be taken into consideration when this neolignan is administered together with other PPAR $y$ agonists used as antidiabetic drugs, such as pioglitazone, rosiglitazone, ciglitazone, and troglitazone. Honokiol enhanced in vitro the effects of rosiglitazone on the activation of PPARy target genes such as adiponectin, glucose transporter type 4 , and adipocyte protein 2 in 3T3-L1 adipocytes, suggesting that it can synergistically stimulate the differentiation and function of adipocytes in combination with endogenous PPARy agonists produced in the early phase of preadipocyte differentiation or clinically administered PPARY agonists.

Numerous studies reported that PPARy agonists, due to their ability to induce cell growth inhibition, cell cycle arrest, or apoptosis of tumor cells, act also as antitumoral agents [64]. Recently, it has been reported that honokiol too exerted an antiproliferative effect on hepatoma cells through the regulation of G0/G1 phaserelated proteins expression and that a more effective inhibition was induced when honokiol was administered with rosiglitazone [58].

Honokiol, alone or combined with chemiotherapeutic agents, can also contribute to reduce the chemioresistance and cancer progression of mammary carcinoma cells by suppressing the expression of multidrug resistance proteins and the transmembrane protein Mucin 1 [65].

It has been recently reported that, like some drugs, magnolol and honokiol interact in vitro with aristolochic acids, suggesting they may interact with other compounds derived from plants as well [66]. However, it is important to note that these data do not necessarily translate into drug interactions in clinical situations, and additional in vivo studies are required to draw firm conclusions on the metabolic drug interactions of magnolol and honokiol. In real-life situations, the same enzymes used to transfer glucuronic acid to drugs and to neolignans also interact with natural polyphenols taken through the diet (e.g., wine, berries, tea). Thus, it remains to be established which of the components of a whole diet are in fact responsible for the putative modulation of drug metabolism. 
- Table 9 Studies involving humans.

\begin{tabular}{|c|c|c|c|c|}
\hline Reference & Subject & Investigation & Treatment & Results \\
\hline$[68]$ & $\begin{array}{l}16 \text { healthy premeno- } \\
\text { pausal women (20-50 } \\
\text { years of age), over- } \\
\text { weight (BMI 25-34.9) }\end{array}$ & $\begin{array}{l}\text { Effect of a dietary supple- } \\
\text { ment containing M. offi- } \\
\text { cinalis extract and Phello- } \\
\text { dendron amurense (Relora) } \\
\text { on anxiety, stress, and } \\
\text { sleep }\end{array}$ & $\begin{array}{l}\text { Relora (corresponding to } \\
11.25 \mathrm{mg} / \mathrm{d} \text { honokiol and } \\
0.75 \mathrm{mg} / \mathrm{d} \text { berberine) or } \\
\text { placebo was administered for } \\
6 \text { wk }\end{array}$ & $\begin{array}{l}\text { Two volunteers in the study group reported } \\
\text { heartburn, trembling hands, perilabial numb- } \\
\text { ness, sexual dysfunction, thyroid dysfunction, } \\
\text { fatigue, and headaches. No serious adverse } \\
\text { events related to treatment were recorded } \\
\text { and no significant alterations in biochemical } \\
\text { markers were found }\end{array}$ \\
\hline [74] & $\begin{array}{l}40 \text { healthy adults at } \\
\text { high risk for caries }\end{array}$ & $\begin{array}{l}\text { Effect of MBE on caries } \\
\text { and gingivitis }\end{array}$ & $\begin{array}{l}\text { Participants chewed five pieces/ } \\
\text { d of sugar-free chewing gum } \\
\text { containing MBE (equivalent to } \\
11.9 \text { mg of magnolol and hono- } \\
\text { kiol) for } 30 \mathrm{~d}\end{array}$ & No side effects were reported \\
\hline [69] & $\begin{array}{l}42 \text { healthy premeno- } \\
\text { pausal women (20-50 } \\
\text { years of age), over- } \\
\text { weight (BMI 25-34.9) }\end{array}$ & $\begin{array}{l}\text { Effect of a dietary supple- } \\
\text { ment containing } M \text {. offici- } \\
\text { nalis extract and Phello- } \\
\text { dendron amurense (Relora) } \\
\text { on weight control }\end{array}$ & $\begin{array}{l}\text { Relora (corresponding to } \\
11.25 \mathrm{mg} / \mathrm{d} \text { honokiol and } \\
0.75 \mathrm{mg} / \mathrm{d} \text { berberine) or } \\
\text { placebo was administered for } \\
6 \text { wk }\end{array}$ & $\begin{array}{l}\text { Side effects “possibly related” to Relora treat- } \\
\text { ment (heartburn, shaking hands, perilabial } \\
\text { numbness, sexual dysfunction, and thyroid } \\
\text { dysfunction) were reported by one partici- } \\
\text { pant. No significant changes in metabolic } \\
\text { profile laboratory values were observed }\end{array}$ \\
\hline$[71]$ & $\begin{array}{l}\text { Nine healthy subjects } \\
\text { with no evidence of sys- } \\
\text { temic or oral pathology }\end{array}$ & $\begin{array}{l}\text { Oral antibacterial effect } \\
\text { of } \mathrm{MBE}\end{array}$ & $\begin{array}{l}\text { Three pieces of compressed } \\
\text { mints (corresponding to a total } \\
\text { of } 12.6 \mathrm{mg} \text { of } \mathrm{MBE} \text { ) were con- } \\
\text { sumed or two pieces of chewing } \\
\text { gums (corresponding to } 4 \mathrm{mg} \text { of } \\
\text { MBE) were chewed for } 20 \mathrm{~min}\end{array}$ & $\begin{array}{l}\text { No general problems related to MBE ingestion } \\
\text { were reported }\end{array}$ \\
\hline$[72]$ & 111 healthy adults & $\begin{array}{l}\text { Effect of MBE on the } \\
\text { formation of oral volatile } \\
\text { sulfur-containing com- } \\
\text { pounds }\end{array}$ & $\begin{array}{l}1 \text { piece of chewing gum con- } \\
\text { taining } 0.012 \%(\mathrm{w} / \mathrm{w}) \text { zinc } \\
\text { acetate and } 0.15 \%(\mathrm{w} / \mathrm{w}) \mathrm{MBE} \\
\text { (equivalent to } 0.14 \%(\mathrm{w} / \mathrm{w}) \\
\text { magnolol) was chewed for } \\
10 \text { min up to } 1 \mathrm{~h}\end{array}$ & $\begin{array}{l}\text { No general problems related to MBE ingestion } \\
\text { was reported }\end{array}$ \\
\hline [73] & 111 healthy adults & $\begin{array}{l}\text { Effect of MBE on the } \\
\text { formation of oral volatile } \\
\text { sulfur-containing com- } \\
\text { pounds }\end{array}$ & $\begin{array}{l}\text { Two tablets containing } 0.17 \mathrm{mg} \\
\text { of zinc lactate and } 0.84 \mathrm{mg} \mathrm{MBE} \\
\text { were ingested (corresponding to } \\
1.64 \mathrm{mg} \text { of } \mathrm{MBE} \text { ) }\end{array}$ & $\begin{array}{l}\text { No general problems related to MBE ingestion } \\
\text { was reported }\end{array}$ \\
\hline
\end{tabular}

\section{Possible Side Effects in Humans}

Although the use of MBE has a long history, especially in traditional Chinese and Japanese medicine, and it is found in many dietary supplements currently consumed worldwide, no epidemiological studies have examined the toxicity of MBE or its derivatives. This may partially be ascribed to the fact that the preparations frequently contain other substances besides $M$. officinalis and the magnolol and honokiol contents in formulations are often not specified. Thus, it is hard to calculate precisely the doses of neolignans consumed or to conduct adequate clinical-epidemiological studies evaluating any toxic effects.

Products containing M. officinalis have recently been marketed as anti-aging cosmetics [67]. Similar to other Magnolia extracts, for MBE, too, allergic contact dermatitis has been reported, so this ingredient might be a rare allergen.

MBE has been employed as functional ingredient in a series of human studies, either alone or with other herbal ingredients ( $\triangleright$ Table 9). In a clinical study with a food supplement comparing MBE and phellodendron with placebo, volunteers were given $11.25 \mathrm{mg} / \mathrm{d}$ of honokiol and $0.75 \mathrm{mg} / \mathrm{d}$ of berberine [68]. Forty- two overweight female volunteers entered the study, and two subjects in the study group and one in the placebo arm withdrew because of adverse effects. The two volunteers in the study group anecdotally reported heartburn, trembling hands, perilabial numbness, sexual dysfunction, thyroid dysfunction, fatigue, and headaches. During the study, however, no serious adverse events related to treatment were recorded and no significant differences in biochemical markers were found between the two groups [68].

In another study which used the same supplement, the same symptoms were reported by two volunteers, although these were judged unrelated to treatment [69]. Furthermore, the blended nature of the supplement makes it impossible to relate any effect to a single constituent.

M. officinalis-based products have recently gained popularity as sedatives, too, on the basis of the ability of magnolol and honokiol to exert GABA-ergic and cannabimimetic activities, alongside the customer's perception of a product which is "natural" and hence somehow "safe" [70]. However, no peer-reviewed papers proving the abuse, misuse, or dependence on or addiction to magnoliabased products have been retrieved yet [70]. 
Concentrated MBE was employed in clinical studies where volunteers ingested a single dose of the extract presented in chewing gum or tablets [71-73]. Considering that about $50 \%$ of MBE was released by chewing gum during the chewing, it can be calculated that, in the study by Greenberg et al. and involving volunteers, 1-4 mg of magnolol plus honokiol was ingested [71]. A similar amount was taken by volunteers enrolled by Porciani et al., in which chewing gum or tablets, releasing respectively $1.5 \mathrm{mg}$ and $3 \mathrm{mg}$ of magnolol plus honokiol, were used [72,73], and no side effects were reported.

In a clinical study involving 40 volunteers, five pieces of chewing gum per $\mathrm{d}$, equivalent to $11.9 \mathrm{mg} / \mathrm{d}$ of total magnolol and honokiol, were chewed for $30 \mathrm{~d}$. It was calculated that this corresponded to a daily intake of about $6 \mathrm{mg}$ neolignans, and again, no volunteer reported side effects [74]. Overall, human studies investigating the efficacy of MBE have encompassed dosages from 1 to about $10 \mathrm{mg}$ of magnolol and honokiol for periods that span from single doses to $1 \mathrm{y}$ and have found no side effects related to the ingestion of the two neolignans.

\section{Additional Information on the Authorization of MBE and Supporting Evidence}

In addition to the studies derived from the structured search and following systematic review, it is important to consider that MBE has been the subject of a series of specific authorizations for use in food. MBE is listed among herbs allowed for used in different European countries such as Italy [75], France [76] and Belgium [77]. In particular, the Belgian decree reported a warning on the use of magnolia extracts in pregnancy or the simultaneous use of anticoagulant drugs. So far, numerous papers have been published on the effects of $M$. officinalis and its active ingredients honokiol and magnolol on hemostasis, and the biochemical mechanisms underlying their effects have been widely investigated in vitro. They were reported to act as inhibitors of thromboxane formation, platelet activation, and aggregation [78], and these effects were confirmed in vivo in rodents. Magnolol was reported to prolong the tail bleeding time of mice when injected i. p., starting from the dose of $10 \mathrm{mg} / \mathrm{kg}$ b. w., whereas no effects were observed at lower doses [79]. Honokiol has recently been reported to inhibit platelet activation and aggregation in rats when injected i.v. at $0.5 \mathrm{mg} / \mathrm{kg}$ b.w. [80]. On the basis of these observations, it is reasonable to establish that the lowest dose of magnolol and honokiol required for antihemostatic action in rodents is $0.5 \mathrm{mg} / \mathrm{kg}$ b. w. when administered i. v. Only two studies are available so far on the effect of magnolia extract in pregnancy and on fetal development. The first one investigated the effects of honokiol and magnolol extracted from $M$. officinalis on muscular contractile responses ex vivo in the nonpregnant rat uterus [81]. Both compounds exerted a spasmolytic effect on uterine muscle contraction and their potential use was envisaged in the treatment of some gynecological disturbances and dysfunction associated with an increase in uterine muscular activity, such as dysmenorrhea and premature delivery. The second study investigated the embryo-fetal developmental toxicity of honokiol microemulsion, a new dosage form of honokiol developed by the Chinese Peking
University [82]. In this study, done under Good Laboratory Practice regulations, honokiol was injected i.v. to pregnant rats at $0.2,0.6$, and $2.0 \mathrm{mg} / \mathrm{kg}$ b.w./d from d $6-15$ of gestation, and body weights, clinical parameters, cesarian sections, and fetal morphology were recorded. The NOAEL of honokiol microemulsion was $0.6 \mathrm{mg} / \mathrm{kg}$ b.w./d [82], which is apparently comparable to the dose effective as antihemostatic in rodents [80]. However, in the same study Zhang et al. [82] concluded that the dose of honokiol microemulsion of $0.6 \mathrm{mg} / \mathrm{kg}$ b. w. $/ \mathrm{d}$ was about 75 times the dosage, which, they hypothesized, would be effective as an antihemostatic in humans.

On the base of these findings one can conclude that the warnings on the effect of magnolia extract in pregnancy are not justified so far. The warning about the use of MBE in pregnancy or simultaneous use of anticoagulant drugs recently issued by the Belgian authorities can be explained by the antihemostatic effect of the extract and the active compounds magnolol and honokiol.

Magnolol is also authorized as a flavoring agent. The specification reported a minimum of $92 \%$ magnolol and 3-7\% honokiol, plus $1-2 \%$ eudesmol. The international organization of the flavor industry referred to an assessment by the joint FAO/WHO expert committee on food additives [76], which identified a NOAEL of $240 \mathrm{mg} / \mathrm{kg}$ b. w./d from the study by Liu et al. [19] and concluded that the intake as a flavoring would be 2400 times lower to ensure an adequate safety margin.

\section{Conclusions}

Magnolol and honokiol are two structurally related neolignans present as the main active compounds in MBE. The Chinese pharmacopeia indicates that extracts intended for traditional therapeutic use should contain at least $0.3 \%$ of neolignans by weight as the sum of the two main components [77]. However, this review focused on concentrated MBE containing more than $90 \%$ total magnolol and honokiol or on the pure compound, thus eliminating confounding effects due to any other constituents of the magnolia bark.

In vitro and in vivo studies have shown that MBE containing more than $92.5 \%$ of magnolol and up to $7.5 \%$ of honokiol do not give rise to any concern as regards mutagenicity or genotoxicity $[2,19,20,22,23]$. Their functional and structural similarity means that magnolol and honokiol have comparable pharmacodynamic and pharmacokinetic properties and are metabolized similarly. When administered orally, about $90 \%$ of both compounds are rapidly excreted in feces and urine [26]. The absorbed fraction is subsequently glucuronidated and only $1 \%$ of the oral dose remains circulating in the free form for $12-16 \mathrm{~h}[1,28,38,39,51]$. Although magnolol and honokiol can be subject to enterohepatic circulation, they do not cause any specific hepatic side effects [2, 27]. In rats, the $L D_{50}$ for $M B E$ was as high as $50 \mathrm{~g} / \mathrm{kg}$ b. w. or more for oral intake but was significantly lower when injected i. p. [45]. The NOAEL based on a $90-\mathrm{d}$ oral study was set at $240 \mathrm{mg} / \mathrm{kg}$ b. w. [49].

No troublesome side effects related to the ingestion of herbal formulations containing MBE or magnolol/honokiol have been reported so far in humans, and $M$. officinalis and obovata have been used for a long time in traditional oriental medicines. 
In recent years the popularity of Magnolia has grown substantially because, similarly to other herbal-derived products, customers perceive it totally "natural" and hence "safe". Concentrated formulations containing magnolia extracts can be easily purchased on the Internet today [70], facilitating self-administration. This raises important questions on the abuse/misuse of magnolia extract and its main constituents and on their ability to interfere with pharmacological treatments, particularly those required for chronic disease management. Nevertheless, the intake of magnolol and honokiol has been modelled for use as a flavoring substance and as a functional ingredient in mints and chewing gum and is considered safe against the reported NOAEL.

\section{Supporting Information}

Additional details on the bibliographic strategy are provided as Supplementary Information.

Acknowledgements

This review was partially supported by Perfetti Van Melle SpA, Italy.

\section{Conflict of Interest}

AS and NK are employees of Perfetti Van Melle Spa. The Department of Molecular Biochemistry and Pharmacology of the IRCCS - Istituto di Ricerche Farmacologiche "Mario Negri" has received scientific consultancy fees from Perfetti Van Melle SpA Company within the last $5 \mathrm{y}$.

\section{References}

[1] Tsai TH, Chou C], Lee TF, Wang LCH, Chen CF. Pharmacokinetic and pharmacodynamic studies of magnolol after oral administration in rats. Pharmaceutical Sciences 1996; 2: 191-193

[2] Lee YJ, Lee YM, Lee CK, Jung JK, Han SB, Hong JT. Therapeutic applications of compounds in the magnolia family. Pharmacol Ther 2011; 130 : 157-176

[3] Poivre M, Duez P. Biological activity and toxicity of the Chinese herb Magnolia officinalis Rehder \& E. Wilson (Houpo) and its constituents. J Zhejiang Univ Sci B 2017; 18: 194-214

[4] Hsieh MT, Chueh FY, Lin MT. Magnolol decreases body temperature by reducing 5-hydroxytryptamine release in the rat hypothalamus. Clin Exp Pharmacol Physiol 1998; 25: 813-817

[5] Wu L, Zou H, Xia W, Dong Q, Wang L. Role of magnolol in the proliferation of vascular smooth muscle cells. Herz 2015; 40: 542-548

[6] Herrmann D, Schreiber A, Ciotkowska A, Strittmatter F, Waidelich R, Stief CG, Gratzke C, Hennenberg M. Honokiol, a constituent of Magnolia species, inhibits adrenergic contraction of human prostate strips and induces stromal cell death. Prostate Int 2014; 2: 140-146

[7] Moher D, Liberati A, Tetzlaff J, Altman DG, Group P. Preferred reporting items for systematic reviews and meta-analyses: the PRISMA statement. PLoS Med 2009; 6: e1000097

[8] Centre for Reviews and Dissemination. Systematic Reviews: CRD's Guidance for Undertaking Reviews in Health Care: Centre for Reviews and Dissemination. Layerthorpe: York Publishing Services; 2009

[9] Yahara S, Nishiyori T, Kohda A, Nohara T, Nishioka I. Isolation and characterization of phenolic compounds from magnoliae cortex produced in China. Chem Pharm Bull (Tokyo) 1991; 39: 2024-2036

[10] Jin-Ping S, Zai-Kang T, Ri-Yan Z. Study of quality of Hou Po. China J Chinese Trad Med 2000; 25: 466-469
[11] Zai-Kang T, Jin-Ping S, Rao L. Study on variation and inheritance of phenolic compound concentrations in Magnolia officinalis of different seed sources. Forest Res 2000; 13: 257-261

[12] Matsuda H, Kageura T, Oda M, Morikawa T, Sakamoto Y, Yoshikawa M. Effects of constituents from the bark of Magnolia obovata on nitric oxide production in lipopolysaccharide-activated macrophages. Chem Pharm Bull (Tokyo) 2001; 49: 716-720

[13] Min BS. Anti-complement activity of phenolic compounds from the stem bark of Magnolia obovate. Nat Prod Sci 2008; 14: 196-201

[14] Choi NH, Choi G], Min BS, Jang KS, Choi YH, Kang MS, Park MS, Choi JE, Bae BK, Kim JC. Effects of neolignans from the stem bark of Magnolia obovata on plant pathogenic fungi. J Appl Microbiol 2009; 106: 20572063

[15] Lee YK, Yuk DY, Kim TI, Kim YH, Kim KT, Kim KH, Lee B], Nam SY, Hong JT. Protective effect of the ethanol extract of Magnolia officinalis and 4O-methylhonokiol on scopolamine-induced memory impairment and the inhibition of acetylcholinesterase activity. J Nat Med 2009; 63: 274282

[16] Jiang Y, Vaysse J, Gilard V, Balayssac S, Dejean S, Malet-Martino M, David B, Fiorini C, Barbin Y. Quality assessment of commercial Magnoliae officinalis Cortex by (1)H-NMR-based metabolomics and HPLC methods. Phytochem Anal 2012; 23: 387-395

[17] Zhao Z, Hu M, Sashida Y, Tang X. Pharmacognostical Studies on the magnolia bark (3). Determination of magnolol and honokiol in "Hou Po" (Cortex Magnoliae) prepared from the bark of different age. Jap J Pharmacogn 1991; 45: 145-147

[18] Lee S, Khoo C, Halstead CW, Huynh T, Bensoussan A. Liquid chromatographic determination of honokiol and magnolol in Hou Po (Magnolia officinalis) as the raw herb and dried aqueous extract. J AOAC Int 2007; 90: $1210-1218$

[19] Li N, Song Y, Zhang W, Wang W, Chen J, Wong AW, Roberts A. Evaluation of the in vitro and in vivo genotoxicity of magnolia bark extract. Regul Toxicol Pharmacol 2007; 49: 154-159

[20] Zhang B, Maniatis T, Song Y, Zhang W, Zhang X, Li N, Chen J, Wong AW Roberts A. Evaluation of magnolia bark extract in chromosomal aberration assays. Mutat Res 2008; 654: 133-137

[21] Nachtergael A, Poivre M, Belayew A, Duez P. In vitro genotoxicity tests point to an unexpected and harmful effect of a magnolia and aristolochia association. J Ethnopharmacol 2015; 174: 178-186

[22] Bai X, Cerimele F, Ushio-Fukai M, Waqas M, Campbell PM, Govindarajan B, Der CJ, Battle T, Frank DA, Ye K, Murad E, Dubiel W, Soff G, Arbiser JL. Honokiol, a small molecular weight natural product, inhibits angiogenesis in vitro and tumor growth in vivo. J Biol Chem 2003; 278: 3550135507

[23] Fried LE, Arbiser JL. Honokiol, a multifunctional antiangiogenic and antitumor agent. Antioxid Redox Signal 2009; 11: 1139-1148

[24] Fujita S, Taira J. Biphenyl compounds are hydroxyl radical scavengers: their effective inhibition for UV-induced mutation in Salmonella typhimurium TA102. Free Rad Biol Med 1994; 17: 273-277

[25] Saito J, Sakai Y, Nagase H. In vitro anti-mutagenic effect of magnolol against direct and indirect mutagens. Mutat Res 2006; 609: 68-73

[26] Hattori M, Endo Y, Takebe S, Kobashi K, Fukasaku N, Namba T. Metabolism of magnolol from magnoliae cortex. II. Absorption, metabolism and excretion of $\left[\right.$ ring $\left.-{ }^{14} \mathrm{C}\right]$ magnolol in rats. Chem Pharm Bull (Tokyo) 1986; 34: $158-167$

[27] Yong-Hua M, Jia-Nan Y, Noboru F, Masao H, Tsuneo N. Metabolism of magnolol from magnoliae cortex (IV): enterohepatic circulation and gastrointestinal excretion of (ring ${ }^{-14} \mathrm{C}$ ) magnolol in rats. Jap | Pharmacogn 1988; 42: 130-134

[28] Bohmdorfer M, Maier-Salamon A, Taferner B, Reznicek G, Thalhammer T, Hering S, Hufner A, Schuhly W, Jager W. In vitro metabolism and disposition of honokiol in rat and human livers. J Pharm Sci 2011; 100: 3506-3516 
[29] Dong Y, Tang M, Song H, Li R, Wang C, Ye H, Qiu N, Zhang Y, Chen L, Wei $\mathrm{Y}$. Characterization of metabolic profile of honokiol in rat feces using liquid chromatography coupled with quadrupole time-of-flight tandem mass spectrometry and (13)C stable isotope labeling. J Chromatogr B Analyt Technol Biomed Life Sci 2014; 953-954: 20-29

[30] Lai H, Tang M, Liu J, Dong Y, Qiu N, Li S, Ma L, Yang J, Song H, Zhang Y, Peng $\mathrm{A}$, Chen L. Identification of honokiol metabolites in rats by the method of stable isotope cluster technique and ultra-high performance liquid chromatography/quadrupole-time-of-flight mass spectrometry. J Chromatogr B Analyt Technol Biomed Life Sci 2013; 931: 157-163

[31] Liu J, Tang M, Lai H, Dong Y, Xie C, Ye H, Ma L, Qiu N, Li Y, Cai L, Chen L. Identification of metabolites of honokiol in rat urine using ${ }^{13} \mathrm{C}$ stable isotope labeling and liquid chromatography coupled with quadrupole timeof-flight tandem mass spectrometry. J Chromatogr A 2013; 1295: 48-56

[32] Jeong HU, Kim JH, Kong TY, Choi WG, Lee HS. Comparative metabolism of honokiol in mouse, rat, dog, monkey, and human hepatocytes. Arch Pharm Res 2016; 39: 516-530

[33] Sang S, Lambert JD, Ho CT, Yang CS. The chemistry and biotransformation of tea constituents. Pharmacol Res 2011; 64: 87-99

[34] Maier-Salamon A, Bohmdorfer M, Thalhammer T, Szekeres T, Jaeger W. Hepatic glucuronidation of resveratrol: interspecies comparison of enzyme kinetic profiles in human, mouse, rat, and dog. Drug Met Pharmacokinet 2011; 26: 364-373

[35] Tsai TH, Chou C], Chen CF. Pharmacokinetics and brain distribution of magnolol in the rat after intravenous bolus injection. J Pharm Pharmacol 1996; 48: 57-59

[36] Tsai TH, Chou CJ, Cheng FC, Chen CF. Pharmacokinetics of honokiol after intravenous administration in rats assessed using high-performance liquid chromatography. J Chromatogr B Biomed Appl 1994; 655: 41-45

[37] Lin SP, Tsai SY, Lee Chao PD, Chen YC, Hou YC. Pharmacokinetics, bioavailability, and tissue distribution of magnolol following single and repeated dosing of magnolol to rats. Planta Med 2011; 77: 1800-1805

[38] Tsai TH, Chou C], Chen CF. Glucuronidation of magnolol assessed using HPLC/fluorescence. Planta Med 1995; 61: 491-492

[39] Homma M, Oka K, Kobayashi H, Niitsuma T, Yamamoto S, Itoh H, Takahashi N. Liquid chromatographic determination of magnolol in urine collected from volunteers after a single dose of saiboku-to, an oriental herbal medicine for bronchial asthma. J Pharm Pharmacol 1993; 45: 839-841

[40] Jun-Jun W, Xiao-Lei M, Jing-Ya C, Yong C. The pharmacokinetics and tissue distribution of honokiol and its metabolites in rats. Eur J Drug Metab Pharmacokinet 2016; 41: 587-594

[41] Liu Y, Wang D, Yang G, Shi Q, Feng F. Comparative pharmacokinetics and brain distribution of magnolol and honokiol after oral administration of Magnolia officinalis cortex extract and its compatibility with other herbal medicines in Zhi-Zi-Hou-Po decoction to rats. Biomed Chromatogr 2016; 30: 369-375

[42] Reagan-Shaw S, Nihal M, Ahmad N. Dose translation from animal to human studies revisited. FASEB J 2008; 22: 659-661

[43] Cheng Z. Comparative studies on the interactions of honokiol and magnolol with human serum albumin. J Pharm Biomed Anal 2012; 66: 240251

[44] Chang HM, But HM, eds. Pharmacology and Applications of Chinese Materia Medica, vol. II. Singapore: World Scientific Publishing Co Pte Ltd; 1986: $878-880$

[45] Ueng T, Kang JJ, Wang HW, Lin PC. An overview of the toxicology of commonly used traditional Chinese medicine. Yao WuShih P'in Fen Hsi (J Food Drug Anal) 1997; 5: 241-264

[46] Yang H, Chen CF. Subacute toxicity of 15 commonly used Chinese drugs (II). J Food Drug Anal 1997; 5: 355-380

[47] Cheng Y, Nuan J, Lin Z, Li Z, Ming G, Zhu-Xin Y. Impairment of kidney induced by methanol extract of Magnolia officinalis after single or chronic administration in mice. Pharmaceut Care Res 2003; 3: 156-159
[48] Yang HY, Chen CF. Pharmacology and toxicology of herbal medicine: subacute toxicity of commonly used Chinese drugs. J Toxicol Sci 1998; 23 (Suppl. 2): 229-233

[49] Liu Z, Zhang X, Cui W, Zhang X, Li N, Chen J, Wong AW, Roberts A. Evaluation of short-term and subchronic toxicity of magnolia bark extract in rats. Regul Toxicol Pharmacol 2007; 49: 160-171

[50] Food and Drug Administration. Good Laboratory Practice for Nonclinical Laboratory Studies; Proposed Rule. Available at https://www.fda.gov/ downloads/AboutFDA/ReportsManualsForms/Reports/Economic Analyses/UCM518224.pdf. Accessed August 1, 2016

[51] Zhu L, Ge G, Liu Y, He G, Liang S, Fang Z, Dong P, Cao Y, Yang L. Potent and selective inhibition of magnolol on catalytic activities of UGT1A7 and 1A9. Xenobiotica 2012; 42: 1001-1008

[52] Zhu L, Ge G, Zhang H, Liu H, He G, Liang S, Zhang Y, Fang Z, Dong P, Finel M, Yang L. Characterization of hepatic and intestinal glucuronidation of magnolol: application of the relative activity factor approach to decipher the contributions of multiple UDP-glucuronosyltransferase isoforms. Drug Metab Dispos 2012; 40: 529-538

[53] Jeong HU, Kong TY, Kwon SS, Hong SW, Yeon SH, Choi JH, Lee JY, Cho YY, Lee HS. Effect of honokiol on cytochrome P450 and UDP-glucuronosyltransferase enzyme activities in human liver microsomes. Molecules 2013; 18: 10681-10693

[54] Yang L, Zhu L, Ge G, Xiao L, Wu Y, Liang S, Cao Y, Yang L, Wang D. Species-associated differences in the inhibition of propofol glucuronidation by magnolol. J Am Assoc Lab Anim Sci 2014; 53: 408-411

[55] Xiao L, Wu Y, Zhu LL. Tissue related differences with inhibition of magnoIol on propofol glucuronidation. Chinese Pharmaceutical J 2016; 18: 1596-1599

[56] Duan J, Xiao J, Chen Y, Han FM. Inhibition of magnolol and honokiol on cytochrome P450 enzymes in rat and human liver microsomes. Chin Herbal Med 2015; 7: 167-172

[57] Rempel V, Fuchs A, Hinz S, Karcz T, Lehr M, Koetter U, Muller CE. Magnolia extract, magnolol, and metabolites: activation of cannabinoid CB2 receptors and blockade of the related GPR55. ACS Med Chem Lett 2013; 4: $41-45$

[58] Chen HC, Hsu HT, Weng JW, Chang YF, Hsia CY, Lee HC, Chi CW. Combined effect of honokiol and rosiglitazone on cell growth inhibition through enhanced G0/G1 phase arrest in hepatoma cells. J Chin Med Assoc 2016; 79: 415-421

[59] Kotani H, Tanabe H, Mizukami H, Amagaya S, Inoue M. A naturally occurring rexinoid, honokiol, can serve as a regulator of various retinoid $\mathrm{x}$ receptor heterodimers. Biol Pharm Bull 2012; 35: 1-9

[60] Kotani H, Tanabe H, Mizukami H, Makishima M, Inoue M. Identification of a naturally occurring rexinoid, honokiol, that activates the retinoid $\mathrm{X}$ receptor. J Nat Prod 2010; 73: 1332-1336

[61] Choi SS, Cha BY, Lee YS, Yonezawa T, Teruya T, Nagai K, Woo JT. Honokiol and magnolol stimulate glucose uptake by activating PI3K-dependent Akt in L6 myotubes. Biofactors 2012; 38: 372-377

[62] Alonso-Castro AJ, Zapata-Bustos R, Dominguez F, Garcia-Carranca A, Salazar-Olivo LA. Magnolia dealbata Zucc and its active principles honokiol and magnolol stimulate glucose uptake in murine and human adipocytes using the insulin-signaling pathway. Phytomedicine 2011; 18: 926-933

[63] Sun J, Fu X, Liu Y, Wang Y, Huo B, Guo Y, Gao X, Li W, Hu X. Hypoglycemic effect and mechanism of honokiol on type 2 diabetic mice. Drug Des Devel Ther 2015; 9: 6327-6342

[64] Borbath I, Horsmans Y. The role of PPARgamma in hepatocellular carcinoma. PPAR Res 2008; 2008: 209520

[65] Thulasiraman P, Johnson AB. Regulation of Mucin 1 and multidrug resistance protein 1 by honokiol enhances the efficacy of doxorubicin-mediated growth suppression in mammary carcinoma cells. Int J Oncol 2016; 49: 479-486 
[66] Bunel V, Antoine MH, Stevigny C, Nortier ], Duez P. New in vitro insights on a cell death pathway induced by magnolol and honokiol in aristolochic acid tubulotoxicity. Food Chem Toxicol 2016; 87: 77-87

[67] Ghys K, De Palma A, Vandevenne A, Werbrouck J, Goossens A. Magnolia officinalis bark extract, a recently identified contact allergen in 'anti-ageing' cosmetics. Contact Dermatitis 2015; 73: 130-132

[68] Kalman DS, Feldman S, Feldman R, Schwartz HI, Krieger DR, Garrison R. Effect of a proprietary magnolia and phellodendron extract on stress levels in healthy women: a pilot, double-blind, placebo-controlled clinical trial. Nutr J 2008; 7: 11

[69] Garrison R, Chambliss WG. Effect of a proprietary magnolia and phellodendron extract on weight management: a pilot, double-blind, placebocontrolled clinical trial. Altern Ther Health Med 2006; 12: 50-54

[70] Schifano F, Guarino V, Papanti DG, Baccarin J, Orsolini L, Corkery JM. Is there a potential of misuse for Magnolia officinalis compounds/metabolites? Hum Psychopharmacol 2017; 32: 3

[71] Greenberg M, Urnezis P, Tian M. Compressed mints and chewing gum containing magnolia bark extract are effective against bacteria responsible for oral malodor. J Agric Food Chem 2007; 55: 9465-9469

[72] Porciani PF, Grandini S. The effect of zinc acetate and magnolia bark extract added to chewing gum on volatile sulfur-containing compounds in the oral cavity. J Clin Dent 2012; 23: 76-79

[73] Porciani PF, Grandini S, Chazine M. The effect of zinc lactate and magnolia bark extract added tablets on volatile sulfur-containing compounds in the oral cavity. J Clin Dent 2014; 25: 53-56

[74] Campus G, Cagetti MG, Cocco F, Sale S, Sacco G, Strohmenger L, Lingstrom $\mathrm{P}$. Effect of a sugar-free chewing gum containing magnolia bark extract on different variables related to caries and gingivitis: a randomized controlled intervention trial. Caries Res 2011; 45: 393-399
[75] Disciplina dell'impiego negli integratori alimentari di sostanze e preparati vegetali. (12A07895) DOI, 2012)Z. Italian Ministry of Health. Available at http://www.salute.gov.it/imgs/C_17_pagineAree_1268_ listaFile_itemName_2_file.pdf. Accessed June 18, 2018

[76] JECFA, ECoFA. Safety evaluation of certain food additives and contaminants. In: World Health Organization, ed. WHO FOOD ADDITIVES SERIES. Geneva, Switzerland: WHO Press, World Health Organization; 2011; 64

[77] Ministry of Health of the People's Republic of China. Pharmacopoeia of the People's Republic of China (English edition). Beijing: China Medical Science Press; 1988

[78] Mohd Nor NH, Othman F, Mohd Tohit ER, Md Noor S. Medicinal herbals with antiplatelet properties benefit in coronary atherothrombotic diseases. Thrombosis 2016; 2016: 5952910

[79] Teng CM, Ko FN, Wang JP, Lin CN, Wu TS, Chen CC, Huang TF. Antihaemostatic and antithrombotic effect of some antiplatelet agents isolated from Chinese herbs. J Pharm Pharmacol 1991; 43: 667-669

[80] Lee TY, Chang CC, Lu W], Yen TL, Lin KH, Geraldine P, Li JY, Sheu JR. Honokiol as a specific collagen receptor glycoprotein VI antagonist on human platelets: functional ex vivo and in vivo studies. Sci Rep 2017; 7: 40002

[81] Lu YC, Chen HH, Ko CH, Lin YR, Chan MH. The mechanism of honokiolinduced and magnolol-induced inhibition on muscle contraction and $\mathrm{Ca}^{2+}$ mobilization in rat uterus. Naunyn Schmiedebergs Arch Pharmacol 2003; 368: 262-269

[82] Zhang Q, Ye X, Wang L, Peng B, Zhang Y, Bao ], Li W, Wei ], Wang A, Jin $\mathrm{H}$, Chen S. Embryo-fetal development toxicity of honokiol microemulsion intravenously administered to pregnant rats. Regul Toxicol Pharmacol 2016; 74: 117-122 